\title{
A methodology based on spatial distribution of parameters for understanding affect of rainfall and vegetation density on groundwater recharge
}

${ }^{1}$ Vijai Singhal and ${ }^{2}$ Rohit Goyal

\begin{abstract}
Accurate estimation of groundwater recharge is extremely important for proper management of groundwater systems. Attempts have been made by various researchers to relate impact of various parameters on groundwater recharge. In the present study, a methodology based on spatial distribution of parameters has been developed for understanding affect of rainfall and vegetation density on groundwater recharge. Normalized Difference Vegetation Index (NDVI) has been used as an indicative parameter for vegetation density. Raster layers of recharge and various parameters were created for the study area and simultaneous values for these parameters were retrieved at the cell level. Zonal analysis was then carried out to understand affect of these parameters on groundwater recharge. It is observed that the value of recharge increases up to a certain value of NDVI, beyond which it starts decreasing with further increase in value of NDVI. The study also reveals a linear trend between groundwater recharge and rainfall. The result of this study does not provide method of calculating recharge by using single parameter such as rainfall or NDVI, however, it explores affect of variation in these parameters on groundwater recharges. The study provides a new insight into the complex interrelationship between groundwater recharge and vegetation density.
\end{abstract}

Keywords: Groundwater recharge, NDVI, Rainfall, Spatial distribution, GIS

\section{Introduction}

Groundwater recharge is the entry into the saturated zone of water made available at the water table surface, together with the associated flow away from the water table within the saturated zone (Freeze and Cherry 1979). Accurate estimation of

${ }^{1}$ Sr. Environmental Engineer, Rajasthan State Pollution Control Board, Jaipur (India), singhalvijai@gmail.com,

${ }^{2}$ Professor, Malviya National Institute of Technology Jaipur (India), rgoyal_jp@yahoo.com 
groundwater recharge is extremely important for proper management of groundwater systems (Healy and Cook 2002). In a country like India, with widely prevalent semi arid and arid climate, quantification of groundwater recharge is a basic prerequisite for efficient water resource management (Ministry of Water Resources 1997). In any groundwater modeling exercise, it is not only essential to know the quantity of the groundwater recharge but also its spatial distribution.

Groundwater recharge is most difficult to measure because it is diffuse and varies both with space and time (Cherkauer 2004). Prediction and assessment of variability of recharge is probably one of the most difficult and important problems to overcome. Across some quite large areas, it appears to show little lateral variability while in other, apparently similar, areas it can range across at least an order of magnitude (Allison et al. 1994).

Researchers have reported dependence of recharge on various parameters such as rainfall, soil type, vegetation, land use and topography (Maitre et al. 1999; Jyrkama et al. 2002; Fayer and Walters 1995). Most of the earlier research work though have studied the impact of these parameters on recharge, however, have not derived interrelationships of groundwater recharge with rainfall and vegetation density. In the present study a new methodology, based on spatial distributions of rainfall and vegetation density has been developed to understand affect of these parameters on groundwater recharge.

\section{Impact of various parameters on groundwater recharge}

The magnitude of recharge at a particular location is influenced by four main factors: climate, soils, vegetation/land use and topography. Other factors can significantly impact recharge by affecting one or more of the main factors (Fayer and Walters 1995). Rainfall is one of the most important climatic parameter which impacts groundwater recharge. Enormous effort has been made to estimate the amount and process of recharge by infiltration using precipitation data (Wu et al. 1996). In the arid sands of Western Rajasthan, recharge rate of 3-10 percent $(20-50 \mathrm{~mm})$ of local average annual rainfall has been estimated by various researchers using tracers (Sukhija et al. 1996). Jyrkama et al. (2002) showed that the combination of temperature and precipitation plays an important role in the amount and timing of recharge in cooler climates. Jan et al. (2007) developed a mathematical equation describing the relationship between the groundwater level increment and the effective accumulated rainfall amount. The resulting groundwater level, conventionally termed the residual groundwater level, was found to linearly depend 
on the effective accumulated rainfall amount. It was also shown that the effective accumulated rainfall amount calculated from the exponential-decay weighting method with a decay parameter of 0.25 reveals a highly-correlated relation to the residual groundwater level increment.

Maitre et al. (1999) have described various impacts of vegetation on groundwater recharge which includes, redirection of precipitation by the vegetation canopy, flow of water to the ground via the surface of the branches and stem called stem flow, retention of water by litter on the ground which is more than bare soil thus improving conditions for infiltration into the soil, creation of channels by the roots for preferential flow of water through the unsaturated zone to the water table particularly in low-permeability soils thereby increasing recharge and extraction of soil water in the unsaturated zone by plant roots to feed transpiration thus decreases the amount of percolating water that reaches the saturated zone.

Since 1960s, scientists have extracted and modeled various vegetation biophysical variables using remotely sensed data. The Normalized Difference Vegetation Index (NDVI) is one such widely adopted index (Jensen 2000). Nicholson and Farrar (1994) examined the variability of NDVI over Bostwana during the period 19821987. Its relationship to rainfall was evaluated from 26 stations representing six vegetation formations and six soil types. The study demonstrated a linear relationship between rainfall and NDVI as long as rainfall does not exceed approximately $500 \mathrm{~mm} / \mathrm{yr}$ or $50-100 \mathrm{~mm} \mathrm{/} \mathrm{month.} \mathrm{Above} \mathrm{these} \mathrm{limits,} \mathrm{a}$ "saturation" response occurs and NDVI increases with rainfall only very slowly. Yuan and Roy (2007) explored the relationships between NDVI and the local level atmospheric constituents consisting of precipitation and temperature in the state of Minnesota from 1990 to 1997. The overall relationship between the different atmospheric constituents and NDVI were found to be broadly consistent with the different types of land uses across the state with the highest correlation located in forested areas. Sergio et al. (2008) used NDVI for quantification of evapotranspiration from the deviations between the observed local value of NDVI and the predicted minimum and maximum NDVI values for two hydrologically-well defined reference conditions representing the minimum and maximum vegetation density given a local long-term water availability index.

Variations in topography also affect recharge. Aller et al. (1987) developed an indexing system for evaluating groundwater pollution potential using hydrogeological settings in which land slope has been taken as one of the factors which affect the movement of contaminate in the groundwater. Slopes which 
provide a greater opportunity for contaminants to infiltrate will be associated with higher ground-water pollution potential. Fayer and Walters (1995) have stated that the degree of slope affects both the receipt of solar radiation and the runoff of surface water. Local scale variations of topography can focus surface runoff in such a way that infiltration is greater and occurs in a shorter time.

\section{Study Area}

For the present study, part of Pali district has been taken as study area to demonstrate the methodology presented in this paper. The climate of Pali district is arid to semi arid with average annual rainfall of around $568 \mathrm{~mm}$ (SRSAC 1999). Most of the rainfall falls during the period of monsoon season (Mid May to mid October). Physiography of Pali district may be termed as sub mountainous having undulated plains with scattered isolated hills. A long chain of Aravalli hills from Ajmer, Rajsamand, Udaipur and Sirohi districts connect Pali district.

Pali city is drained by river Bandi, which is a tributary of Luni river. It flows southwest in the Marwar area across the plains of the region and joins River Luni approx $58 \mathrm{~km}$ west of Pali city at village Lakhar Thumb. River Bandi is mostly a dry river except in monsoon season and carries domestic and industrial waste water from the city up to $40 \mathrm{Km}$ (NEERI 1993). The main water bearing formation in the study area is alluvium which comprises of about $60 \%$ of the total area. The depth of water table in the study area varies from $136 \mathrm{~m}$ to 380 from MSL. Fig. 1 shows the location of the study area.
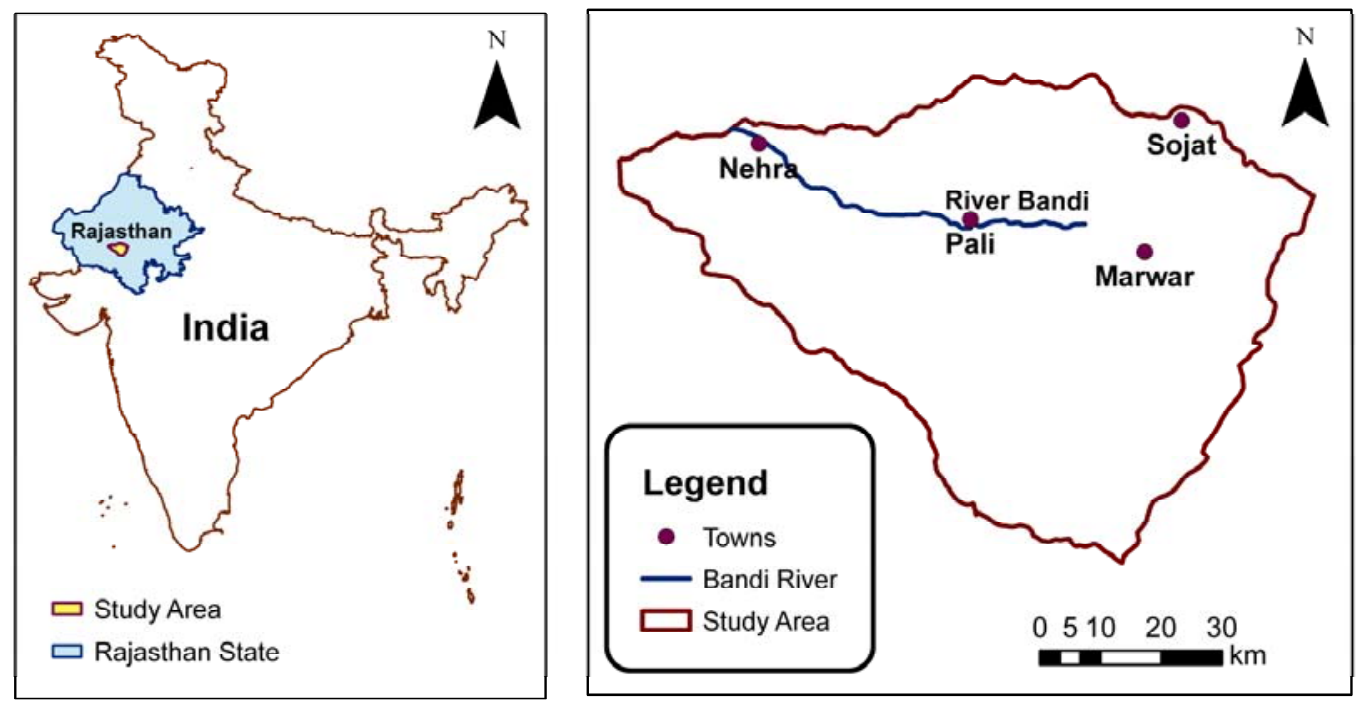

Fig. 1. Study Area 


\section{Methodology}

In the present study data obtained for the study area from various sources such as Central Ground Water Board (CGWB), State Ground Water Department (SGWD), State Irrigation Department (SID), Survey of India (SoI) and remote sensing data have been used to create GIS database. A new methodology has been suggested for understanding affect of some of the parameters on groundwater recharge based on spatial distributions of these parameters. The result of this study does not provide method of calculating recharge by using single parameter such as rainfall or NDVI, however, it explores affect of variation in these parameters on groundwater recharges. This methodology has been amply demonstrated in remote sensing applications such as urban heat island studies (Yuan and Bauer 2007; Zhang et al. 2009) but in the present study, has been shown to be equally applicable for understanding affect of rainfall and vegetation density on recharge.

\section{Development of GIS Database}

108 monitoring wells maintained by CGWB and SGWD and falling within and around the study area and having consistent record were selected to digitize water table levels. Pre and post monsoon groundwater levels of year 2003 to 2006 of these wells were used to calculate groundwater rise for monsoon season. Monsoon season was taken as middle of May to middle of October. The monitoring well rise data were then used to generate water surface rise layers for different monsoon periods using natural neighborhood interpolation technique. Natural neighbor interpolation finds the closest subset of input samples to a query point and applies weights to them based on proportionate areas in order to interpolate a value (Sibson 1981). It works equally well with regularly and irregularly distributed data (Watson 1992).

Location and rainfall data for monsoon periods from year 2003 to 2006 of 20 rain gauge stations falling in and around study area was obtained from SID and was digitized into a point layer. Rainfall surfaces were also interpolated for each monsoon period from year 2003 to 2006 using natural neighborhood interpolation technique.

District hydrogeology map from SoI was used to digitize broad hydrogeological units within the study area. It is observed that three different type of hydrogeological 
units exists in the study area with $61.5 \%$ of the area is alluvium, $21 \%$ is phylite and rest is granite. The area in the western side is mostly alluvium with small patches of granite while eastern area is primarily consists of hard rock aquifer in the form of phylite. On the northern side, granite is found in the upper part of the study area. Fig. 2 shows Hydrogeological map of the study area. Specific yield values of these formations were taken as 0.04 for alluvium and 0.02 for phylite and granite based on the information available in literature (CGWB 1994; SGWD 2005).
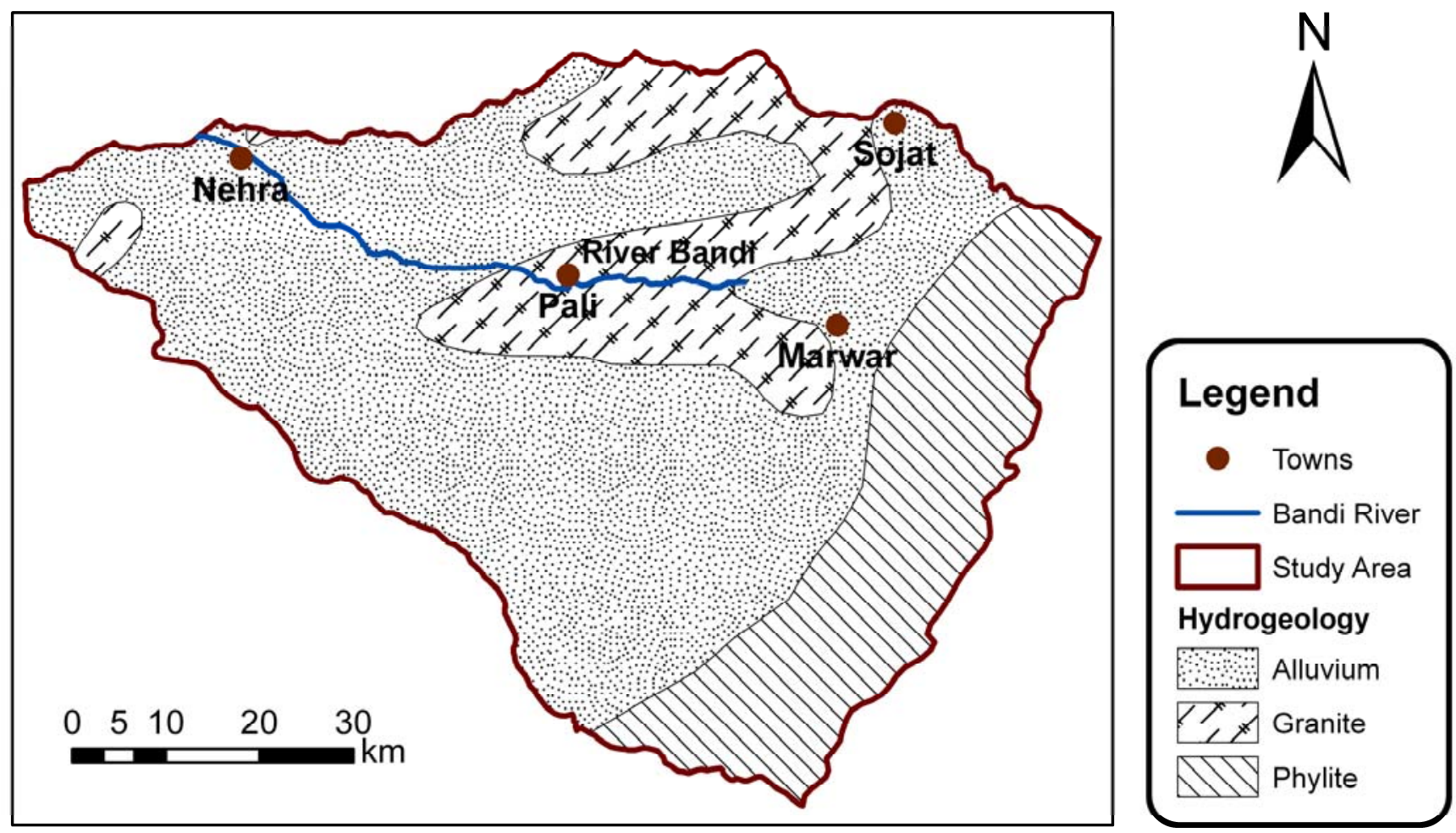

Fig. 2. Hydrogeological map of the study area.

In the present study NDVI has been used as a parameter defining vegetation density of the study area. USGS Land Processes Distributed Active Archive Center (LP DAAC) website provides global NDVI data, derived from MODIS data, every 16 days at approximately 500-meter spatial resolution as a gridded level-3 product in the Sinusoidal projection (LP DAAC website 2010). NDVI products of the study area for 1-16 May, of the beginning of monsoon season, for years 2003 to 2006 were downloaded from LP DAAC website and were used to find out the effect of pre monsoon vegetation density on the recharge. Fig. 3 shows the NDVI map of the study area for the period of 1-16 May 2006. 

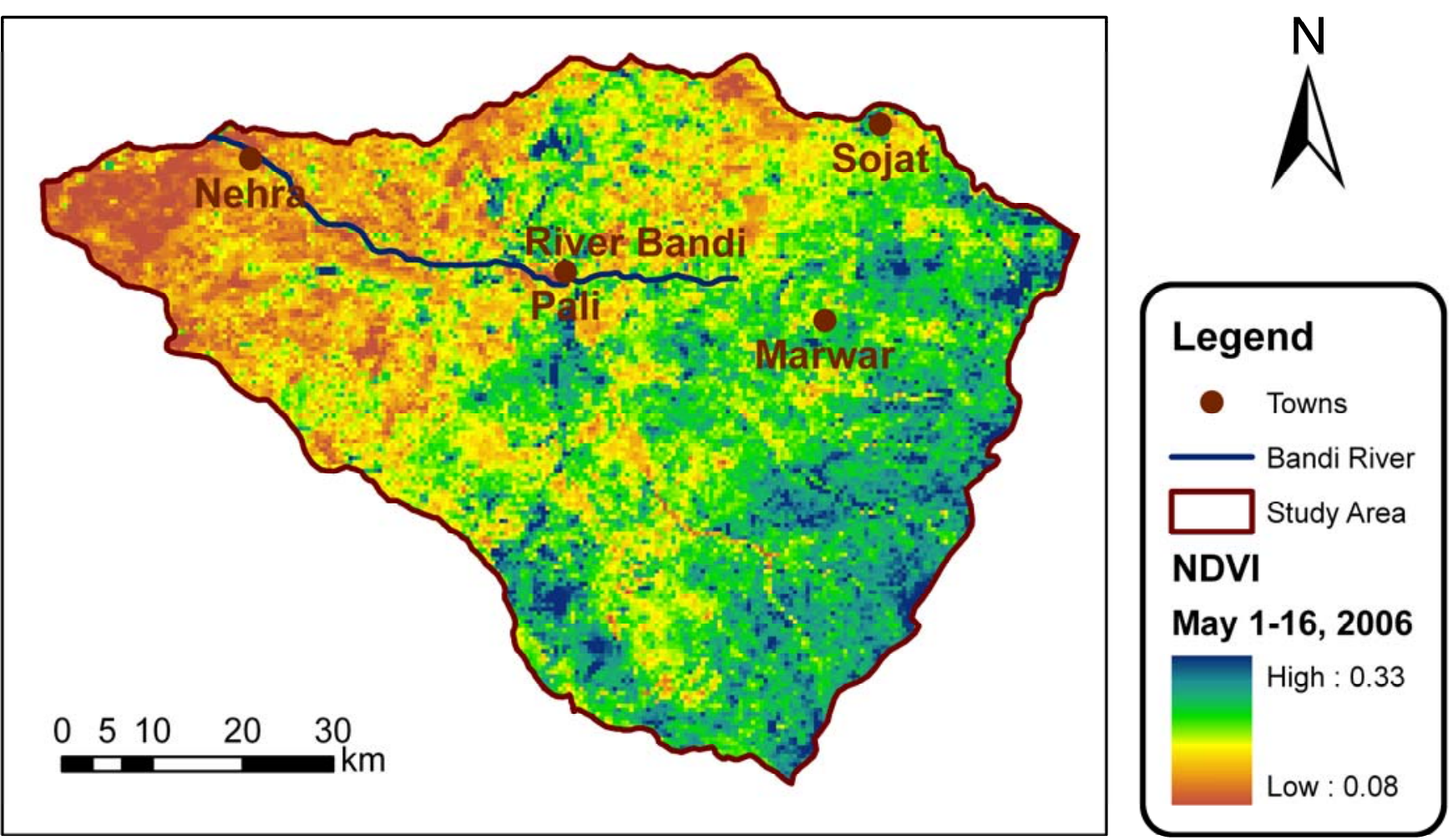

Fig. 3. MODIS NDVI map of May 2006.

\section{Data Analysis}

In order to understand the affect of various parameters, all the different layers, discussed above, were re sampled at the same resolution of $463.3 \mathrm{~m}$ and were snapped to the same base image. Every data layer thus contained same number of overlapping 23,902 active cells representing the study area. Utilizing raster to ASCII (simple text) converter, corresponding cell values were retrieved from different layer and a database was created. These data were arranged in tabular format providing simultaneous values of parameters such as cell number, year, water table rise, rainfall, NDVI etc. Groundwater recharge was also calculated for each cell by multiplying the values of water level rise with specific yield value. Table 1 shows sample data of few randomly selected adjacent cells. Since data for four different years (2003 to 2006) were used, therefore a total of 95,608 different rows of data were generated. 
Table 1. Sample data

\begin{tabular}{|c|c|c|c|c|c|}
\hline $\begin{array}{c}\text { Cell } \\
\text { Number }\end{array}$ & Year & $\begin{array}{c}\text { Water Level } \\
\text { Rise (m) }\end{array}$ & $\begin{array}{c}\text { Rainfall } \\
\mathbf{( m m )}\end{array}$ & $\begin{array}{c}\text { NDVI (1- } \\
\text { 16 May) }\end{array}$ & $\begin{array}{c}\text { Calculated } \\
\text { Groundwater } \\
\text { Recharge (m) }\end{array}$ \\
\hline 871 & 2003 & 0.79 & 406 & 0.142 & 0.032 \\
\hline 872 & 2003 & 0.93 & 403 & 0.143 & 0.037 \\
\hline 873 & 2003 & 1.07 & 400 & 0.157 & 0.043 \\
\hline 874 & 2003 & 1.21 & 398 & 0.147 & 0.048 \\
\hline 875 & 2003 & 1.36 & 395 & 0.137 & 0.054 \\
\hline
\end{tabular}

\section{Results and Discussions}

Database has been analyzed to understand affect of rainfall and NDVI on groundwater recharge. A zonal analysis was carried out to calculate mean value of groundwater recharge at each $1 \mathrm{~mm}$ increment of rainfall. Fig. 4 shows the graph between mean value of groundwater recharge and rainfall. Only those values of rainfall where minimum 100 cells were available within study area have been considered. It can be seen that overall there is a linear trend between groundwater recharge and rainfall. A reasonably strong correlation with coefficient of regression $\left(\mathrm{r}^{2}\right)$ value of 0.781 is obtained.

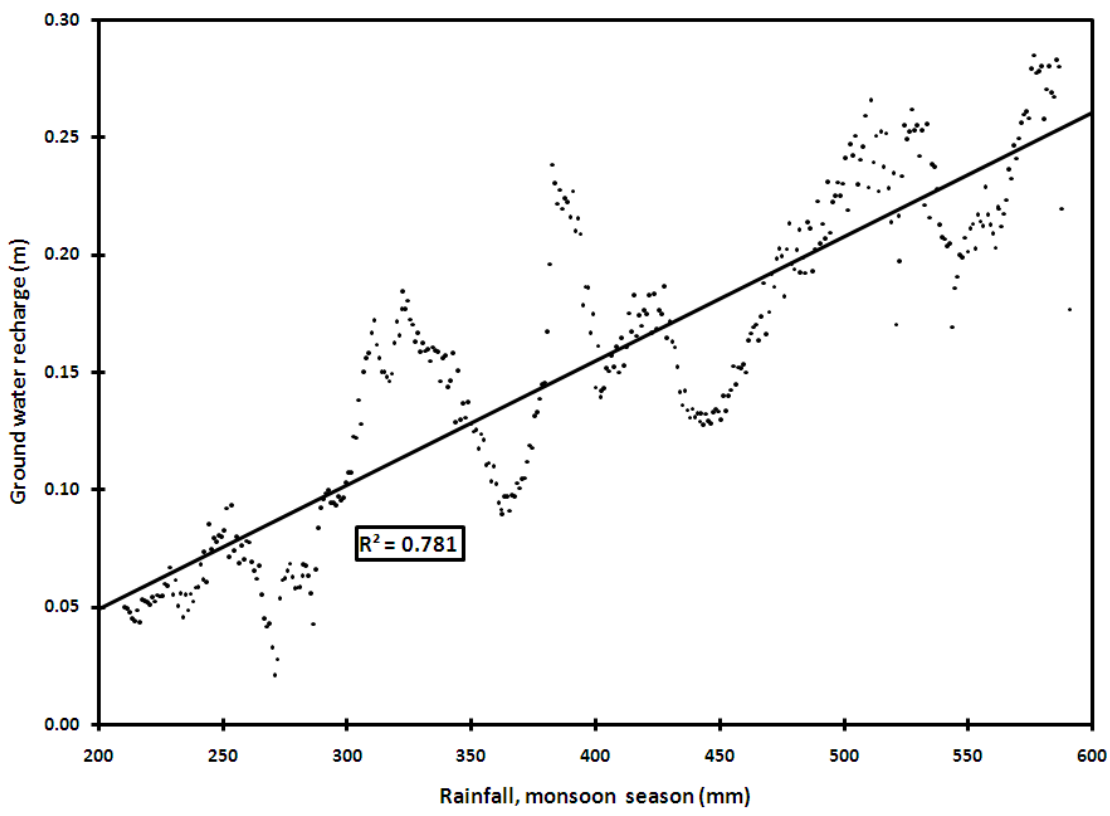

Fig. 4. Graph between rainfall (monsoon season) Vs groundwater recharge 
Similarly graph is obtained between NDVI value and groundwater recharge. Zonal analysis was carried out to calculate mean value of groundwater recharge at each 0.001 increment of NDVI value. Fig. 5 shows the graph between the two values. Only those values of NDVI for which minimum 100 cells were available have been considered. A much stronger correlation has been obtained between mean value of groundwater recharge and NDVI as compared with rainfall. As can be seen from Fig. 5, a strong polynomial trend of second order exists with correlation coefficient of 0.858 . The value of groundwater recharge depends strongly upon the density of vegetation before the monsoon. With increase in value of NDVI from 0.13 to about 0.18 the value of groundwater recharge increases. This is expected as at this level of vegetation; water is retained at the surface due to increase in vegetation density and thus has stronger chance of infiltrating into the ground. However, when the value of NDVI is beyond 0.18 , the groundwater recharge starts decreasing with increase in NDVI value. This would be due to the reason that vegetation density has now increased to such a level that the interception and absorption of water out weights the factors responsible for further increase in recharge.

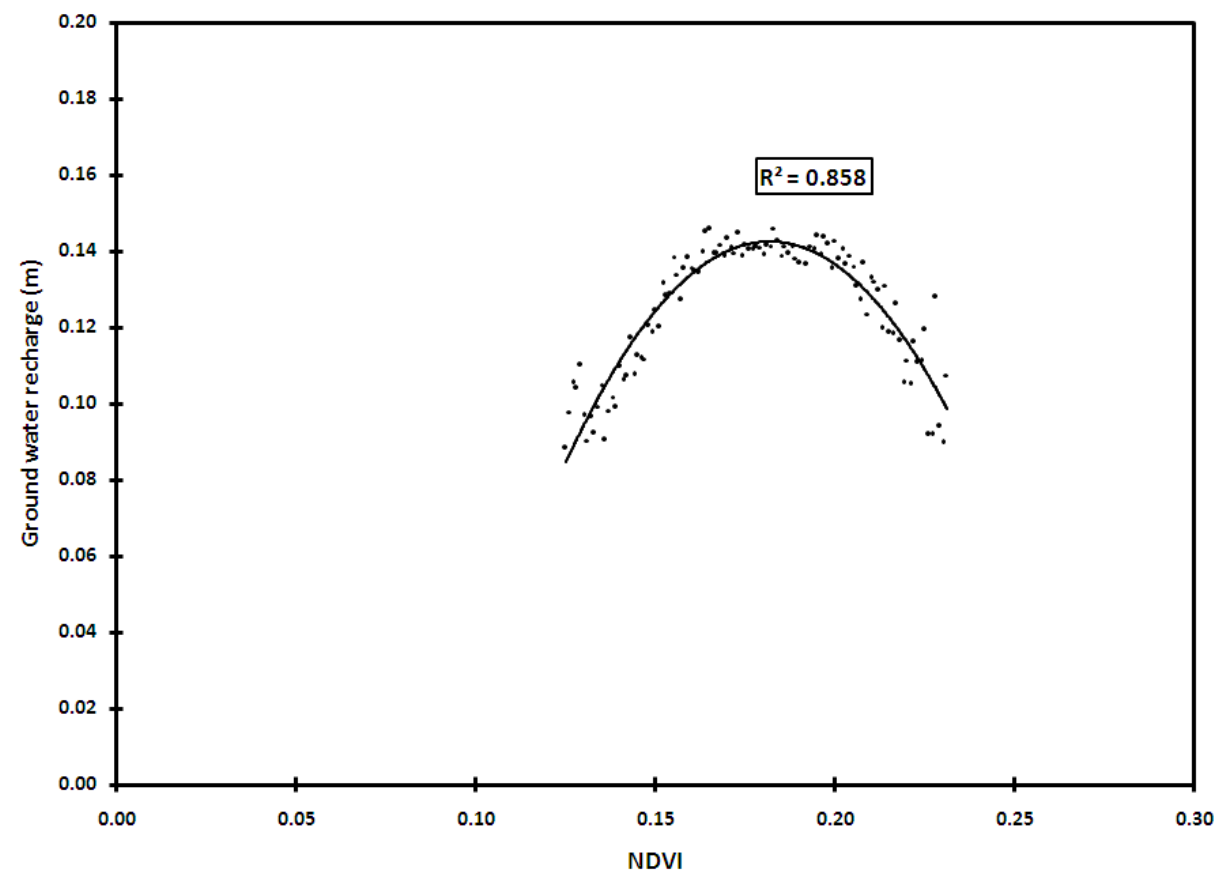

Fig. 5. Graph between NDVI Vs groundwater recharge 


\section{Conclusions}

This study brings out a new methodology for understanding affect of rainfall and vegetation density on groundwater recharge based on spatial distributions of these parameters in a given geographical area. The study also establishes a very strong polynomial correlation of second degree between groundwater recharge and NDVI indicating increase in recharge with increase in NDVI values up to a certain level. Beyond this value there is a decrease in recharge with further increase in value of NDVI. This relationship has been explained based on retention, interception and absorption of water by vegetation. Relationship between rainfall and recharge is also strong having an expected linear trend. This methodology provides a new insight into the complex relationship between groundwater recharge and vegetation density which will help researchers in better understanding of behavior of groundwater recharge and allow improved estimation of the same. This relationship between recharge and vegetation density may also be useful in delineating artificial ground recharge zones based on NDVI.

\section{References}

Aller, L., Bennett, T., Lehr, J. H., Petty, R. J., and Hackett, G. (1987) DRASTIC, A standardized system for evaluating groundwater pollution potential using hydrogeological settings. USEPA.

Allison, G. B., Gee, G. W., and Tylor, S. W. (1994) Vadose-zone techniques for estimating groundwater recharge in arid and semi arid regions. Soil Science Soc. Am. J. 58:6-14.

CGWB (Central Groundwater Board) (1994) Hydrology and groundwater resources of Pali district, Rajasthan (revised). Western Region, Jaipur, March.

Cherkauer, D. S. (2004) Quantifying groundwater recharge at multiple scales using PRMS and GIS. Groundwater, Vol. 42, No.1. National Groundwater Association, USA.

Fayer, M. J., Gee, G. W., Rockhold, M. L., Freshley, M. D., and Walters, T. B. (1996) Estimating Recharge Rates for a Groundwater Model using a GIS. J. Environ Quality.

Fayer, M. J. and Walters, T. B. (1995) Estimation of recharge rates at the Hanford site U.S. Department of Energy.

Freeze, R. A, and Cherry, J. A. (1979) Groundwater. Prentice-Hall, Englewood Cliff, N.J. 
Healy, R. W., and Cook, P. G. (2002) Using groundwater levels to estimate recharge. J. Hydrogeology, Springer-Verlag. Systems

Jan, C., Chen, T. H., and Lo, W. C. (2007) Effect of rainfall intensity and distribution on groundwater level fluctuations. J. Hydrology, 332, 348- 360

Jensen, J. R. (2000) Remote Sensing of The Environment: An Earth Resource Perspective, Pearson Education, Inc. Delhi, pp. 361-365

Jyrkama, M. I., and Sykes, J. F. (2002) Recharge estimation for transient groundwater modeling. Groundwater, Vol. 40, Issue 6, November, pp. 638-648.

LP DAAC website (2010) URL: https://lpdaac.usgs.gov/. Accessed on 14 March 2010.

Maitre, D. C. Le, Scott, D. F., and Colvin, C. (1999) A review of information on interactions between vegetation and groundwater. Water SA Vol. 25 No., April.

Ministry of Water Resources (1997) Groundwater Resource Estimation Methodology 1997, Government of India, Report. June

NEERI (National Environmental Engineering Research Institute) (1993) Basic engineering package for Common Effluent Treatment Plant (CETP) at Pali, Rajasthan. Nagpur, August

Nicholson, S. E., and Farrar, T. J. (1994) The influence of soil type on the relationships between NDVI, precipitation, and soil moisture in semiarid Botswana. I. NDVI response to precipitation. Remote Sensing of Environment, 50(2): 107-120.

Sergio, C., Matthias, M. B., Francisco, J. A., Francisco, D., Mónica, G., Antonio, P., and Juan, P. (2008) An ecohydrological modeling approach for assessing long-term recharge rates in semiarid karstic landscapes. J. Hydrology Vol. 351, Issues 1-2, 30 March, pp. 42-57.

SGWD (State Groundwater Department) (2005) Reappraisal of groundwater resources of Pali district as on 31.03.04. January.

Sibson, R. (1981) A brief description of natural neighbor interpolation," Chapter 2 in Interpolating multivariate data, John Wiley \& Sons, New York, pp. 21-36.

SRSAC (State Remote Sensing Application Centre) (1999) Groundwater Atlas of Rajasthan, Jodhpur. Report

Sukhija, B. S., Nagabhushanam, P., and Reddy, D. V. (1996) Groundwater recharge in semiarid regions of India. An overview of results obtained using tracers. J. Hydrogeology Vol. 4, Number 3. 
Watson, D. (1992) Contouring: A guide to the analysis and display of spatial data". Pergamon Press, London, 1992.

Wu, J., Zhang, R., and Yang, J. (1996) Analysis of rainfall-recharge relationships. J. Hydrology Vol. 177, issues 1-2, 15 March, pp. 143-160.

Yuan, F., and Bauer, M. E. (2007) Comparison of impervious surface area and normalized difference vegetation index as indicators of surface urban heat island effects in LANDSAT imagery. Remote Sensing of Environment, 106, pp. 375-386.

Yuan, F., and Roy, S. S. (2007) Analysis of the relationship between NDVI and climate variables in Minnesota using geographically weighted regression and spatial interpolation. Proc. of ASPRS 2007 Annual conference, Tampa, Florida. May 7-11.

Zhang, Y., Odeh, I. O. A., and Han, C. (2009) Bi-temporal characterization of land surface temperature in relation to impervious surface area, NDVI and NDBI using a sub-pixel image analysis. International Journal of Applied Earth Observation and Geoinformation, 11, pp. 256-264. 